\title{
Dendranthema zawadskii var. lucidum (Nakai) J.H. Park Extract Inhibits Cellular Senescence in Human Dermal Fibroblasts and Aging-Related Inflammation in Rats
}

\author{
Jehun Choi ${ }^{1}$, Gwi-Yeong Jang ${ }^{1}$, Jeonghoon Lee ${ }^{1}$, Hae-Young Chung ${ }^{2}{ }^{\oplus}$, Hyung-Jun Noh ${ }^{1}$, Geum-Soog Kim ${ }^{1}$ \\ and Seung-Eun Lee ${ }^{1, *}$ \\ 1 Department of Herbal Crop Research, National Institute of Horticultural and Herbal Science (NIHHS), RDA, \\ Eumseong 27709, Korea; jehun@korea.kr (J.C.); janggy@korea.kr (G.-Y.J.); artemisia@korea.kr (J.L.); \\ jumpspace@korea.kr (H.-J.N.); kimgs0725@korea.kr (G.-S.K.) \\ 2 Department of Pharmacy, Pusan National University, Busan 46241, Korea; hyjung@pusan.ac.kr \\ * Correspondence: herbin3@korea.kr
}

check for updates

Citation: Choi, J.; Jang, G.-Y.; Lee, J.; Chung, H.-Y.; Noh, H.-J.; Kim, G.-S.; Lee, S.-E. Dendranthema zawadskii var. lucidum (Nakai) J.H. Park Extract Inhibits Cellular Senescence in Human Dermal Fibroblasts and Aging-Related Inflammation in Rats. Processes 2021, 9, 801. https:// doi.org/10.3390/pr9050801

Received: 9 April 2021

Accepted: 30 April 2021

Published: 2 May 2021

Publisher's Note: MDPI stays neutral with regard to jurisdictional claims in published maps and institutional affiliations.

Copyright: (c) 2021 by the authors. Licensee MDPI, Basel, Switzerland. This article is an open access article distributed under the terms and conditions of the Creative Commons Attribution (CC BY) license (https:/ / creativecommons.org/licenses/by/ $4.0 /)$.

\begin{abstract}
Senescence is the phenomenon by which physiological functions of organisms degenerate with time. Cellular senescence is marked by an inhibition of cell cycle progression. Beta-galactosidase accumulates in the lysosomes of aged cells. In this study, human dermal fibroblast cells (HDFs) were treated with $0.5 \mu \mathrm{M}$ doxorubicin for $4 \mathrm{~h}$ to induce cellular senescence. Senescence-associated beta-galactosidase (SA- $\beta$-gal) activity was then measured $72 \mathrm{~h}$ after treatment with aerial parts of Dendranthema zawadskii var. lucidum (Nakai) J.H. Park (DZ) extract. Treatment with DZ extract significantly decreased SA- $\beta$-gal activity in a dose-dependent manner in HDFs. Additionally, DZ extract treatment reduced age-related oxidative stress and inflammation in the aortas of aged rats. The reactive oxygen species (ROS) levels in aortas of aged control rats were higher than those in young rats. However, DZ extract-fed aged rats showed significantly lower ROS levels than the aged control rats. When the aged rats were treated with DZ extract at either 0.2 or $1.0 \mathrm{mg} \cdot \mathrm{kg}^{-1} \cdot \mathrm{day}^{-1}$, NF- $\mathrm{KB}$ levels in aorta tissue decreased significantly compared to those in aorta tissue of the aged control rats without DZ treatment. In addition, DZ extract-fed aged rat aortas showed significant reductions in expression of iNOS and COX-2 induced by NF- $\mathrm{BB}$ translocation. Therefore, these results suggest that DZ effectively inhibited senescence-related NF- $\mathrm{B}$ activation and inflammation. DZ extract may have a role in the prevention of the vascular inflammatory responses that occur during vascular aging.
\end{abstract}

Keywords: senescence; aging; inflammation; Dendranthema zawadskii var. lucidum

\section{Introduction}

Senescence is a phenomenon that leads to the degeneration of body functions of organisms over time. As senescence progresses, many events such as decreases in the ability to respond to stress, changes in homeostasis, increases of disease risks and ultimately progressing to death happens in organisms.

Senescence of a cell, which is the basic unit of an organism, is determined by the loss of its ability to divide. Senescence is observed as the increasing level of beta-galactosidase (SA$\beta$-gal), an enzyme produced in aged cells that hydrolyzes $\beta$-galactoside to monosaccharides. Cells in the senescence state are stained blue at $\mathrm{pH} 6.0$ by X-Gal, which is caused by the accumulation of beta-galactosidase in lysosomes of aged cells, and this phenomenon has been widely used as a biomarker of cellular senescence [1].

The basic functions of reactive oxygen species (ROS) produced in the body are disinfection and sterilization of foreign materials or microorganisms that infiltrate from outside, and removal of pathogens that penetrate the body. However, chronic production of ROS in aged animals damages cellular components, inducing senescence or senile diseases [2]. 
ROS damage proteins, which lead to a decline in their cellular functions; oxidize lipids and sugars, thereby reducing cellular function; and produce various toxic materials, including lipid peroxide and carbohydrate oxide, which cause further cellular damage. Numerous cells are damaged by these chain reactions; this enhances the senescence of individual cells of the human body along with various senile diseases [3].

Dendranthema zawadskii var. lucidum (Nakai) J.H. Park (DZ) is a perennial dicotyledon that belongs to the order Asterales and family Compositae. It is a special plant found on Ulleungdo, an island of Korea, which has been designated as a rare and endangered species by the Korea Forestry Service. It grows naturally in areas with abundant sunshine on Ulleungdo Island and is resistant to dehydration and drought. DZ avoids moist areas and prefers well-drained places [4]. In oriental medicine, the whole plant is used as a medicine for women's health issues, cerebral palsy, loss of appetite, and neuralgia [5]. Plants that belong to the genus Dendranthema of the Compositae family have been known from ancient times to have excellent medicinal effects, and various plant species of this family have been used as food articles and medicines. It has been reported that flowers of Dendranthema boreale (Makino) Ling ex Kita. have central nervous system (CNS) sedation, hypotensive, and antiviral effects [6]. In addition, flowers of Dendranthema indicum (L.) Des Moul. reportedly have antipyretic, anti-inflammatory, hypotensive, and headache curing effects [7], and aromatic components reportedly have antioxidant effects [8]. Some studies on Dendranthema zawadskii var. latilobum were reported to have activities including protection on liver damage [9], inhibitory effect on osteoclast differentiation [10], and anti-osteoarthritic mechanisms [11]. However, DZ was studied only as a plant of the Ulleungdo [12] and on its antioxidant effects [13]. Moreover, no studies have investigated the inhibitory effects of DZ extracts or its isolated components on cellular senescence in cells or aging by using animal models.

Therefore, in this study, DZ extract was investigated for its possible inhibitory effects against doxorubicin-induced aging in skin fibroblasts. In addition, the extract was examined for its effects on aging-related changes in inflammatory proteins of the vascular tissue from aged rats.

\section{Materials and Methods}

\subsection{Materials}

\subsubsection{Plant Resource and Extract Preparation}

The aerial parts of Dendranthema zawadskii var. lucidum (Nakai) J.H. Park (DZ) were collected July 2012 in Eumseong-gun, a province located in Chungcheongbuk-do in Korea. A specimen of the plant was deposited in the herbarium of the NIHHS and was authenticated by an expert and researcher on plant taxonomy. The voucher number of the plant was given as MPS003034. The plant powder containing selected aerial parts was extracted at room temperature with $100 \%$ ethanol two times. The whole extract was evaporated in vacuum conditions to eliminate the solvent, and $7.52 \mathrm{~g}$ of the extract was obtained from $100 \mathrm{~g}$ of the plant powder.

\subsubsection{Chemicals}

Fibroblast growth medium for the fibroblast cells was purchased from Promo Cell (Heidelberg, Germany). Antibiotic and antimycotic solutions were obtained from Welgene (Daegu, Republic of Korea). Fetal bovine serum was supplied from HyClone (Logan, USA). Antibodies against NF-kB p65, COX-2, NOS-2, TF2B, and $\beta$-actin as well as secondary antibodies were purchased from Santa Cruz Biotech. Inc. (Santa Cruz, CA, USA). N-acetylcysteine and doxorubicin were purchased from Sigma-Aldrich Chemical Co. (St. Louis, MO, USA). Phenolic compounds used for HPLC analysis were purchased from Chengdu Biopurify Phytochemicals Ltd. (Chengdu, Sichuan, China). 


\subsection{Cell Line and Cell Culture}

Normal primary human dermal fibroblast cells (HDFs) were purchased from ATCC (Walkersville, MD, USA). HDfs in fibroblast growth medium with antibiotic solution (penicillin 100 units $/ \mathrm{mL}$ and streptomycin $100 \mu \mathrm{g} / \mathrm{mL})$ and antimycotic solution $(0.25 \mu \mathrm{g} / \mathrm{mL}$ amphotericin B) were sown at $1 \times 10^{5}$ cells per $100 \mathrm{~mm}$ culture plate and incubated at $37^{\circ} \mathrm{C}$ in $5 \% \mathrm{CO}_{2}$ humidified air. Subcultures was performed by trypsinization when the cells reached approximately $80-90 \%$ confluence. The number of population doublings (PDs) were calculated using the geometric equation PD $=\log _{2} \mathrm{~F} / \log _{2} \mathrm{I}$ (F, final cell number; $\mathrm{I}$, initial cell number). HDFs at a PD $<35$ were used for doxorubicin-induced cellular senescence, while HDFs at a PD $>75$ were used to represent old cells under replicative senescence [14,15].

\subsection{Cell Viability Assay}

Cell viability was determined using the MTT (3-(4,5-dimethylthiazol-2-yl)-2,5diphenyltetrazolium bromide) assay. $\mathrm{HDFs}\left(5 \times 10^{2}\right.$ cells) were distributed per well of a 96-well plate and treated with DZ extract for 3 days in $5 \% \mathrm{CO}_{2}$ humidified air. Cells were treated with $0.1 \%$ MTT solution for $3 \mathrm{~h}$ after which the media was discarded, and the resulting formazan crystals were solubilized with $100 \mu \mathrm{L}$ DMSO. Viability was assessed by measuring the absorbance at $550 \mathrm{~nm}$ using a microplate reader (Synergy HT, Bio-Tek instruments INC., Winooski, VT, USA).

\subsection{Induction of Cellular Senescence by Doxorubicin}

HDFs in fibroblast growth medium were plated at $1.5 \times 10^{5}$ cells per $100 \mathrm{~mm}$ culture plate. The cells were incubated at $37^{\circ} \mathrm{C}$ in $5 \% \mathrm{CO}_{2}$ atmospheric condition for 3 days and then were seeded into 48-well plates. One day later, cells were washed with medium and treated with $0.5 \mu \mathrm{M}$ doxorubicin for $4 \mathrm{~h}$ and were then rinsed three times with medium. The doxorubicin-treated HDFs were incubated for 4 days with DZ extract, and then cellular senescence was assessed [16,17].

\subsection{Senescence-Associated $\beta$-Galactosidase (SA- $\beta$-gal) Activity Assay}

Senescence of HDFs was determined by the SA- $\beta$-gal method. Cells were fixed with $3.7 \%$ paraformaldehyde in PBS and then incubated in staining solution $(40 \mathrm{mM}$ citric acid/phosphate, $\mathrm{pH} 5.8,5 \mathrm{mM}$ potassium ferrocyanide, $5 \mathrm{mM}$ potassium ferricyanide, $150 \mathrm{mM} \mathrm{NaCl}, 2 \mathrm{mM} \mathrm{MgCl} 2,1 \mathrm{mg} / \mathrm{mL}$ X-gal) at $37^{\circ} \mathrm{C}$ for $16-18 \mathrm{~h}$. Cells were then washed twice with PBS. Total 100 cells were then counted in five randomized fields. The doxorubicin-treated group was scored as a percentage of cells exhibiting senescence [1].

\subsection{Experimental Animals and Treatment}

Young (5-month-old) and old (15-month-old) specific-pathogen-free (SPF) SpragueDawley (SD) male rats were obtained from Samtako (Osan, Korea). The animals were housed individually in polycarbonate cages with wood chip bedding in an air-conditioned animal room (temperature, $23{ }^{\circ} \mathrm{C}$; relative humidity, $55 \pm 5 \%$ ) with a $12 \mathrm{~h} \mathrm{light/dark}$ cycle. The young rats were fed with only the sterilized diet ad libitum. The aged rats were divided into 3 groups ( $n=6$, each group); they were equalized with respect to the mean body weight and fed the diets for 7 days. The control group of the aged rats was fed with only the sterilized diet ad libitum. The other 2 groups of the aged rats were fed with DZ extract $\left(0.2\right.$ and $1 \mathrm{mg} / \cdot \mathrm{kg}^{-1} \cdot$ day $\left.^{-1}\right)$ and the sterilized diet. After 7 days, the rats were sacrificed by decapitation. The descending aorta was quickly removed and was rinsed in ice-cold saline. The aorta was immediately immersed in liquid nitrogen and was stored at $-80^{\circ} \mathrm{C}$. No significant changes were caused by DZ extract supplementation in the body weights and the food intakes in the aged rats. Blood of each group was collected. After clotting at room temperature (RT) for $30 \mathrm{~min}$ prior to centrifugation at $2000 \times g$ for $30 \mathrm{~min}$ at $4{ }^{\circ} \mathrm{C}$, serum samples were prepared and stored at $-80^{\circ} \mathrm{C}$ until further analyses. The protocol used in this animal study was reviewed and approved by the Committee of 
Institutional Animal Care and Use at the National Institute of Horticultural and Herbal Science, RDA (Authorization Number: NIHHS 2014-002).

\subsection{Tissue Preparation and Measurement of Oxidative Stress}

Aortas were homogenized in 7 volumes $(v / w)$ of ice-cold homogenization solution A (10 mM HEPES, pH 7.8, 10 mM KCl, 2 mM MgCl, 1 mM DTT, 0.1 mM EDTA, 0.1 mM PMSF, $1 \mathrm{mg} / \mathrm{mL}$ pepstatin, and $1 \mathrm{mg} / \mathrm{mL}$ leupeptin). The homogenates were kept on ice for 20 min and mixed with $125 \mu \mathrm{L}$ of $10 \%$ Nonidet P (NP)-40 solution for $15 \mathrm{~s}$. To separate the fraction containing the pelleted nucleus and cytosol, the homogenate mixture was centrifuged at $14,000 \times g$ for $10 \mathrm{~min}$ at $4{ }^{\circ} \mathrm{C}$. The pelleted nucleus was washed with $225 \mu \mathrm{L}$ of buffer B (200 $\mu \mathrm{L}$ of buffer A plus $25 \mu \mathrm{L}$ of $10 \% \mathrm{NP}-40)$ and re-centrifuged at $14,000 \times g$ for $1 \mathrm{~min}$. The final pellets were re-suspended in $100 \mu \mathrm{L}$ of buffer $(50 \mathrm{mM}$ HEPES, $\mathrm{pH}$ 7.8, $50 \mathrm{mM} \mathrm{KCl}, 300 \mathrm{mM} \mathrm{NaCl}, 0.1 \mathrm{mM}$ PMSF, and 10\% glycerol), incubated for $30 \mathrm{~min}$ on ice, and centrifuged at $14,000 \times g$ for $15 \mathrm{~min}$. Protein concentration was measured by performing the bicinchoninic acid assay [18].

To determine the levels of total reactive oxygen species (ROS) including superoxide radicals, hydroxyl radicals, and hydrogen peroxide, a fluorometric assay was used. Nonfluorescent 2,7-dichlorodihydrofluorescein diacetate (DCF-DA) was oxidized to the highly fluorescent 2,7-dichlorofluorescein (DCF) in the presence of esterases and ROS. DCF-DA $(25 \mu \mathrm{M})$ was added to the $10 \mu \mathrm{L}$ of aorta homogenate to create a final volume of $250 \mu \mathrm{L}$. Changes in fluorescence intensity were measured every $5 \mathrm{~min}$ for $30 \mathrm{~min}$ on a fluorescence plate reader with excitation and emission wavelengths set at 485 and $535 \mathrm{~nm}$, respectively.

\subsection{Western Blot Analysis of Aorta Tissue}

Protein expressions of NF-kB p65, TF2B, iNOS, and COX-2 of rat descending aorta tissue were detected using ECL Western blotting reagent detection. Aorta tissue homogenate was boiled for 5 min with a gel-loading buffer ( $\mathrm{pH}$ 6.8, 0.125 M Tris- $\mathrm{HCl}, 4 \%$ SDS, 20\% glycerol, $10 \%$ 2-mercaptoethanol, and $0.2 \%$ bromophenol blue) at a ratio of $4: 1$. The total protein-equivalents for each sample were separated using SDS-polyacrylamide mini gel at $100 \mathrm{~V}$ and then transferred to a PVDF membrane at $80 \mathrm{~V}$ for $2 \mathrm{~h}$ in a wet transfer system. The membrane was immediately placed into blocking solution (5\% skim milk powder in TBS-Tween buffer containing $10 \mathrm{mM}$ Tris- $\mathrm{HCl}, 100 \mathrm{mM} \mathrm{NaCl}$, and 0.1\% Tween-20, pH 7.5) for $1 \mathrm{~h}$ at room temperature. The membrane was then incubated with a primary antibody (0.5\% skim milk, diluted 1:200 in TBS-Tween buffer) at RT for $5 \mathrm{~h}$ and was followed by $1 \mathrm{~h}$ of incubation with a horseradish peroxidase-conjugated secondary antibody at room temperature. Horseradish peroxidase-conjugated secondary antibody labeling was detected using an ECL Western blotting reagent detection and analysis system. A prestained blue protein marker (GangNam-Stain, Intron Biotechnology INC, Seongnam, Korea) was utilized for the determination of molecular weight. The Western blot band was filmed and measured using a ChemiDoc Imaging System (Bio-rad, Hercules, CA, USA) [19].

\subsection{Phenolic Compound Analysis Using a HPLC-UVD}

The phenolic compounds of DZ extract were analyzed using high performance liquid chromatography with a UV-visible detector (HPLC-UVD system: 1200 Series, Agilent Technologies, Santa Clara, California, USA; column: Fusion-RP C18, $250 \times 4.6 \mathrm{~mm}$ id, $4 \mu \mathrm{m}$ particle size, Phenomenex, Torrance, CA, USA). The mobile phase of the analytical system consisted of $0.1 \%$ formic acid in acetonitrile (A) and $0.1 \%$ formic acid in water (B), using the following gradient conditions: $0 \mathrm{~min}(2 \% \mathrm{~A}), 0-5 \mathrm{~min}(2-2 \% \mathrm{~A}), 5-12 \mathrm{~min}(2-5 \% \mathrm{~A})$, 12-17 $\min (5-8 \% \mathrm{~A}), 17-65 \mathrm{~min}(8-30 \% \mathrm{~A}), 65-68 \mathrm{~min}(30-30 \% \mathrm{~A}), 68-78 \mathrm{~min}(30-50 \% \mathrm{~A})$, 78-100 $\min (50-100 \% \mathrm{~A})$, and 100-110 $\mathrm{min}(100-100 \% \mathrm{~A})$. The flow rate, injection volume, and detection wavelength were set at $1.0 \mathrm{~mL} / \mathrm{min}, 10 \mu \mathrm{L}$, and $340 \mathrm{~nm}$, respectively. 


\subsection{Statistical Analysis}

All data in the present study were presented as mean \pm standard error. Statistical significance was determined by one-way ANOVA with a following Tukey multiple comparison test. A $p$ value of $<0.05$ was considered statistically significant.

\section{Results}

\subsection{Inhibition of Cellular Senescence in HDFs by DZ Extract}

HDFs cells were treated with $0.5 \mu \mathrm{M}$ doxorubicin for $4 \mathrm{~h}$ to induce senescence, followed by treatment with DZ extract and incubation for $72 \mathrm{~h}$, after which the cytotoxicity of the DZ extract was examined. HDFs treated with $2-20 \mu \mathrm{g} / \mathrm{mL}$ of DZ extract showed no cytotoxicity (Figure 1).

(A)

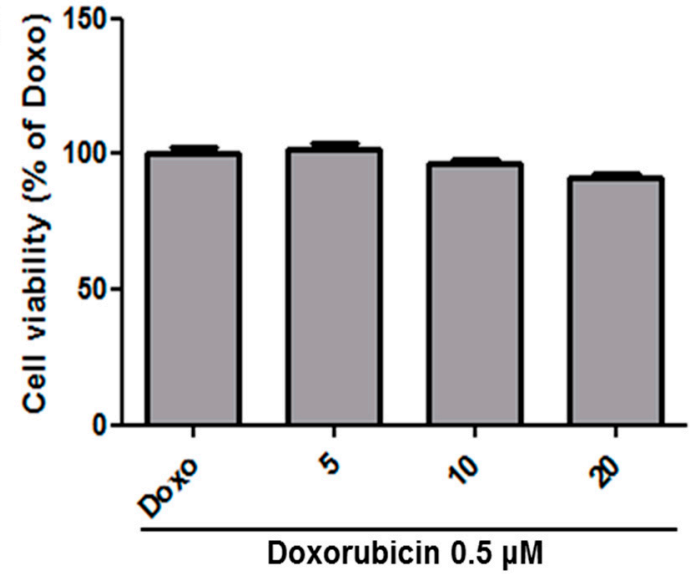

(B)

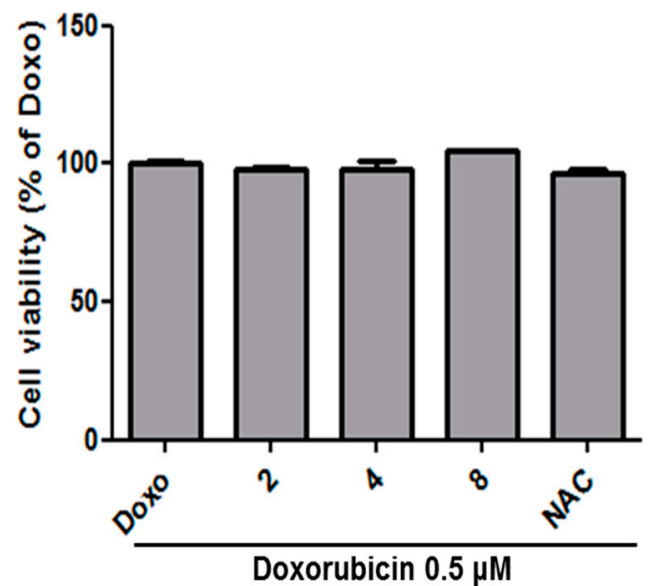

Figure 1. Cell viability of human dermal fibroblasts (HDFs) treated with Dendranthema zawadskii (DZ) extract. Cell viability was measured by the MTT assay. Cells were treated with $0.5 \mu \mathrm{M}$ doxorubicin for $4 \mathrm{~h}$. After $24 \mathrm{~h}$ incubation, cells were treated with DZ extract and incubated for 3 days. Cell viability was measured at $550 \mathrm{~nm}$. (A) Cell viability with 5, 10, $20 \mu \mathrm{g} / \mathrm{mL}$ DZ extract. (B) Cell viability with 2, 4, $8 \mu \mathrm{g} / \mathrm{mL} \mathrm{DZ} \mathrm{extract} \mathrm{and} 5 \mathrm{mM} \mathrm{N}$-acetyl-L-cysteine.

HDF cells were treated with $0.5 \mu \mathrm{M}$ doxorubicin for $4 \mathrm{~h}$ to induce cellular senescence, treated with DZ extract, and incubated for $72 \mathrm{~h}$, and then SA- $\beta$-gal activity was measured [1]. Then, the SA- $\beta$-gal activity of the senescence-induced HDF cells mediated by treatment with $0.5 \mu \mathrm{M}$ doxorubicin for $4 \mathrm{~h}$ was set to $100 \%$. The SA- $\beta$-gal activities of the cells treated with DZ extract at 5 and $20 \mu \mathrm{g} / \mathrm{mL}$ were $29.99 \pm 8.84$ and $11.62 \pm 0.60 \%$, respectively. From the experiment, DZ extract dose-dependently and significantly decreased the SA- $\beta$-gal activity in HDF cells (Figure 2). In addition, SA- $\beta$-gal activities were examined after treatment with DZ extract at 2,4 , and $8 \mu \mathrm{g} / \mathrm{mL}$, and cellular senescence was significantly inhibited in a concentration-dependent manner (Figure 3). 
(A)
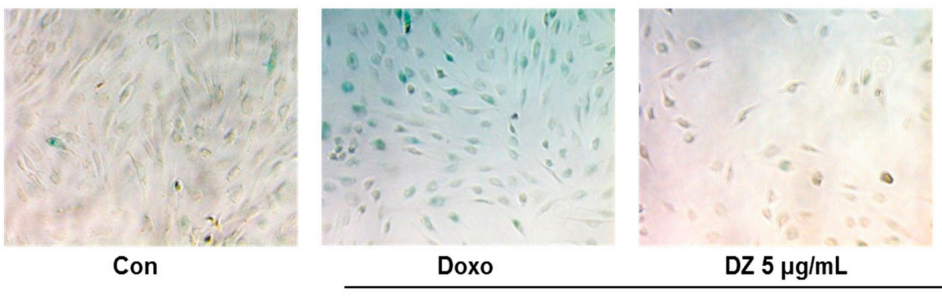

$\mathrm{DZ} 5 \mu \mathrm{g} / \mathrm{mL}$

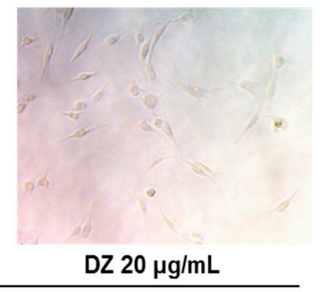

Doxorubicin $0.5 \mu \mathrm{M}$

(B)

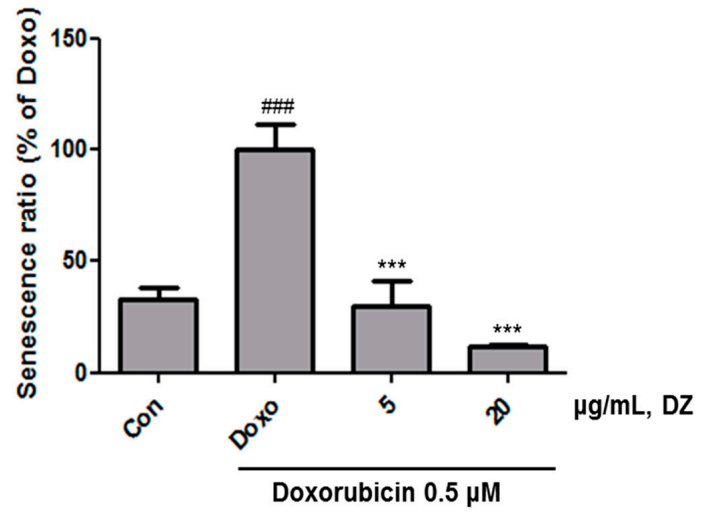

Figure 2. Suppression of doxorubicin-induced cellular senescence in HDFs by Dendranthema zawadskii (DZ) extract. Cellular senescence was assessed by SA- $\beta$-gal activity staining. HDFs were treated with $0.5 \mu \mathrm{M}$ doxorubicin for $4 \mathrm{~h}$. After $24 \mathrm{~h}$ incubation, cells were treated with $5,20 \mu \mathrm{g} / \mathrm{mL} \mathrm{DZ} \mathrm{extract} \mathrm{and} \mathrm{incubated} \mathrm{for} 3$ days. Then, cellular senescence was measured. (A) SA- $\beta$-gal activity staining $(\times 100)$. (B) Cellular senescence ratio. Percentages of staining cells. Values are the means \pm SEs from three independent experiments measured in triplicate. Con, control; Doxo, cells were treated with $0.5 \mu \mathrm{M}$ doxorubicin for $4 \mathrm{~h}$. Statistical significance: \#\#\# $<0.001$ compared to Con. ${ }^{* *}<0.001$ compared to Doxo, respectively.

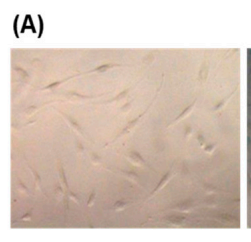

Con

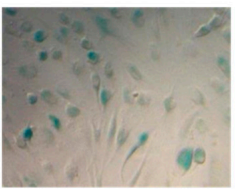

Doxo

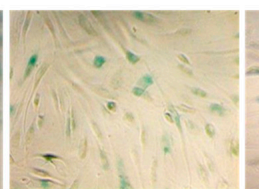

$\mathrm{Dz} 2 \mu \mathrm{g} / \mathrm{mL}$

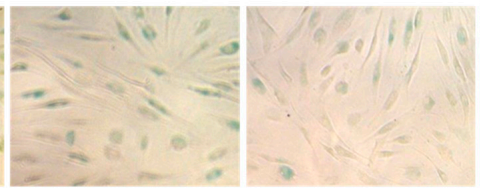

$\mathrm{Dz} 4 \mu \mathrm{g} / \mathrm{mL}$

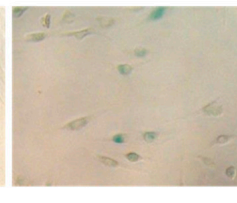

NAC

(B)

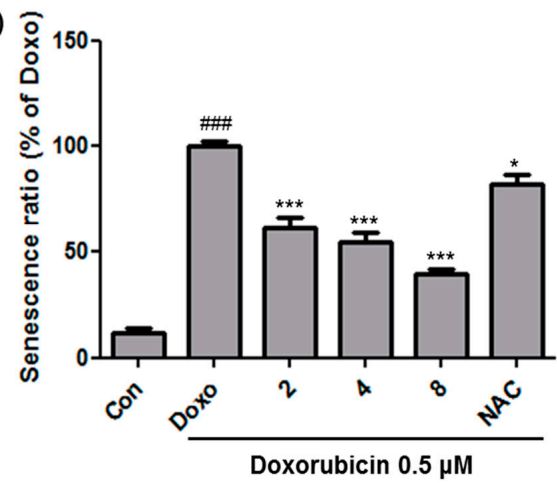

Doxorubicin $0.5 \mu \mathrm{M}$

Doxor 


\subsection{Effects of DZ Extract on Redox Status in the Descending Aorta of Aged Rats}

We assessed the levels of oxidative stress using the dichlorofluorescin diacetate (DCFDA) method to measure levels of ROS in descending aorta homogenates. The results showed that ROS levels in the aged control rats were higher than in young rats; however, the DZ extract-fed aged rats showed significantly lower ROS levels than the aged, DZ extract untreated rats (Figure 4).

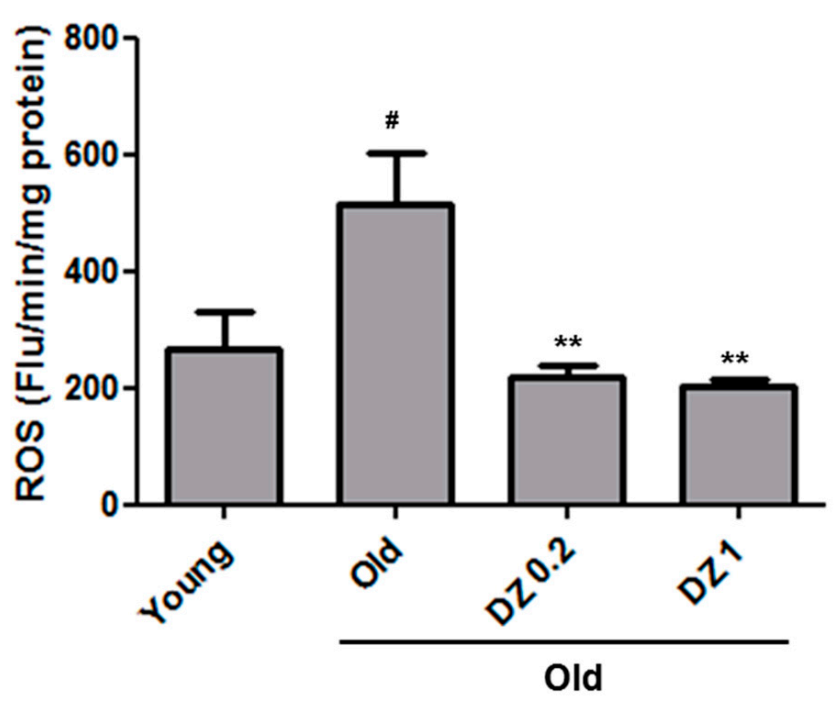

Figure 4. Suppression of ROS level in rat aorta by Dendranthema zawadskii (DZ) extract. ROS level was determined using the DCFDA method in rat aorta homogenate. Each value is the mean \pm S.E. of six rats. Young, 5-month-old rats; Old, 15-month-old rats; DZ 0.2, 15-month-old rats treated with DZ extract $(0.2 \mathrm{mg} / \mathrm{kg} /$ day) for 1 week; DZ 1, 15-month-old rats treated with DZ extract $\left(1 \mathrm{mg} / \mathrm{kg} /\right.$ day) for 1 week. Statistical significance: $\#<0.05$ compared to young. ${ }^{* *}<0.01$ compared to old, respectively.

\subsection{Suppressive Effect of DZ Extract on Age-Induced Nuclear Factor}

Kappa-Light-Chain-Enhancer of Activated B Cells (NF- $\kappa B$ ) Activation and Inflammation in Rat Aorta

In the present study, aged rats were fed with DZ extract at $0.2-1 \mathrm{mg} \cdot \mathrm{kg}^{-1} \cdot \mathrm{day}^{-1}$ for $7 \mathrm{~d}$ to test if DZ extract treatment inhibited the activation of NF- $\mathrm{kB}$, which is supposedly induced by senescence in aortic tissues. In addition, we tested whether DZ extract treatment inhibited the expression of COX-2 and iNOS induced by NF-kB activation. Determination of NF- $\mathrm{kB}$ production in cell nuclei isolated from rat aortic tissues showed that the levels increased in aged rats compared with young rats. DZ extract treatment at $0.2-1 \mathrm{mg} \cdot \mathrm{kg}^{-1} \cdot \mathrm{day}^{-1}$ significantly and dramatically decreased NF- $\mathrm{kB}$ levels in aged rats compared with untreated old rats (Figure 5). In addition, DZ extract-fed aged rats showed significant reductions in senescence-induced NF- $\mathrm{kB}$ activation as well as iNOS and COX-2 expressions induced by NF- $\mathrm{kB}$ translocation (Figure 6). These results suggest that DZ extract effectively inhibited age-related NF- $\mathrm{KB}$ activation and inflammation. 
(A)

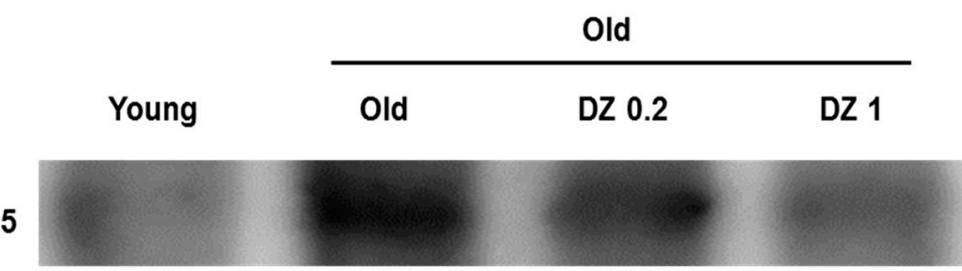

TFIIB

(B)

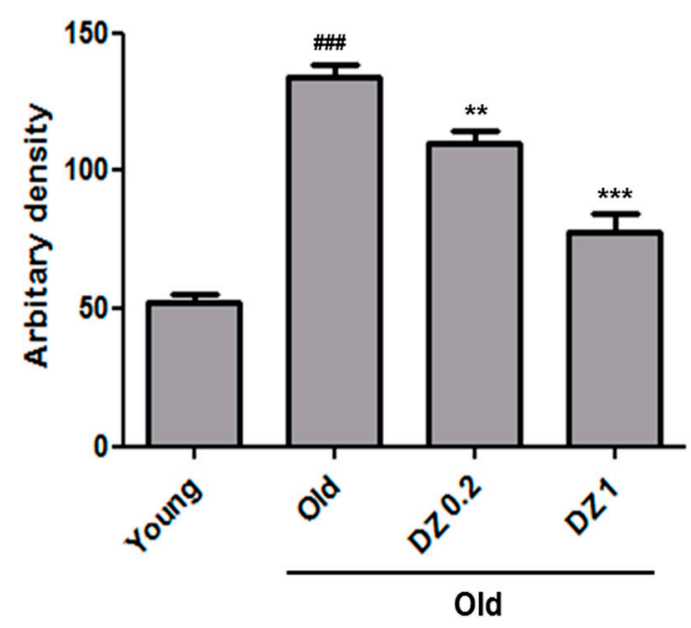

Figure 5. Inhibition of NF- $\mathrm{kB}$ translocation in rat aorta by Dendranthema zawadskii (DZ) extract. (A) Western blot analysis was performed to detect NF-kB p65 protein level in nuclear extract (30 $\mu \mathrm{g}$ protein), aorta tissue from each group. Young, 5-month-old rats; Old, 15-month-old rats; DZ 0.2, 15-month-old rats treated with DZ extract $(0.2 \mathrm{mg} / \mathrm{kg} /$ day) for 1 week; DZ 1, 15-month-old rats treated with DZ extract (1 mg/kg/day) for 1 week. (B) Density analysis of NF- $\mathrm{kB}$ p65. Statistical significance: \#\#\# $<0.001$ compared to young. ${ }^{* *}<0.01$ compared to old, ${ }^{* * *}<0.001$ compared to old, respectively.

\subsection{Major Phenolic Compounds of Dendranthema zawadskii (DZ) Extract}

By HPLC analysis, it was obtained as a result that major phenolic compounds of DZ extract were isochlorogenic acid A, 4-O-caffeoylquinic acid, linarin and isochlorogenic acid C, and their contents were 26,477.89, 16,985.07, 16,480.55 and 10,598.95 $\mu \mathrm{g} / \mathrm{g}$ in extract, respectively (Figure 7 , Table 1 ). 
(A)

\begin{tabular}{llll} 
& \multicolumn{3}{c}{ Old } \\
\cline { 2 - 4 } Young & Old & DZ 0.2 & DZ 1
\end{tabular}

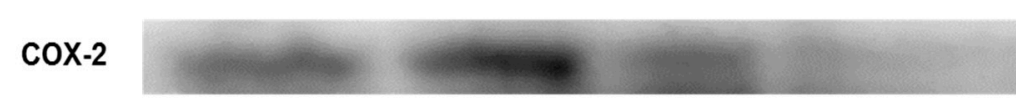

iNOS

$\beta$-actin

(B)

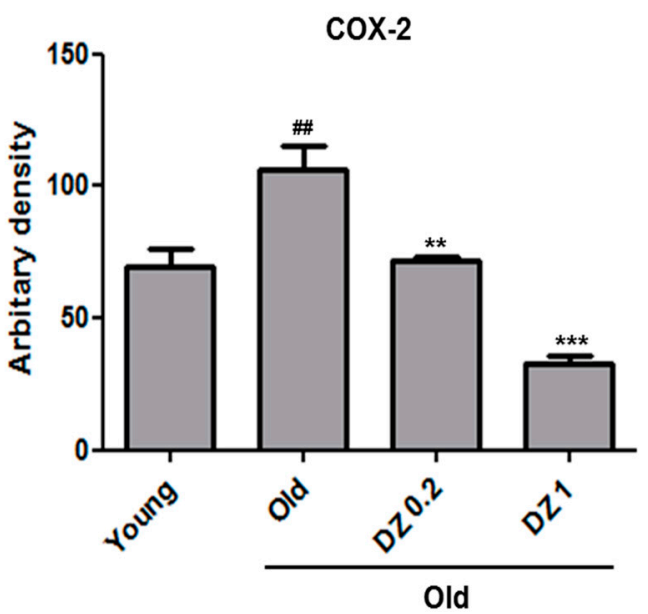

(C)

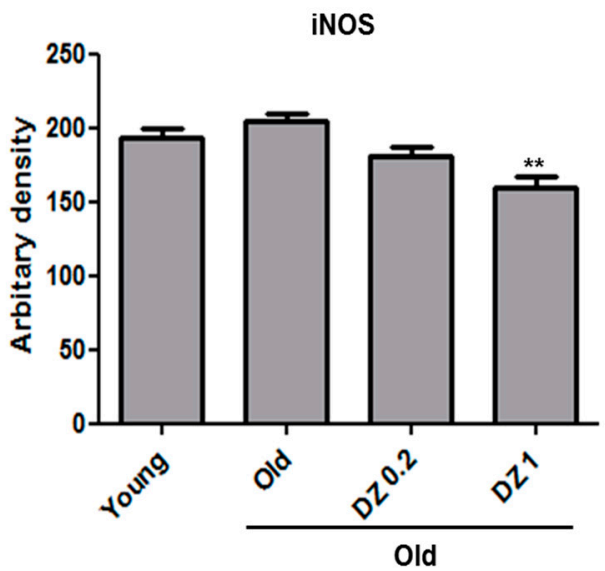

Figure 6. Inhibition of COX-2 and iNOS expression in rat aorta by Dendranthema zawadskii (DZ) extract. (A) Western blot analysis was performed to detect COX-2 and iNOS protein level in cytosol extract (40 $\mu \mathrm{g}$ protein), aorta tissue from each group. Young, 5-month-old rats; Old, 15-month-old rats; DZ 0.2, 15-month-old rats treated with DZ extract $(0.2 \mathrm{mg} / \mathrm{kg} /$ day) for 1 week; DZ 1, 15month-old rats treated with DZ extract (1 mg/kg/day) for 1 week. (B) Density analysis of COX-2. Statistical significance: \#\# $<0.01$ compared to young, ${ }^{* *}<0.01$ compared to old, ${ }^{* * *}<0.001$ compared to old, respectively. (C) Density analysis of iNOS. Statistical significance: ${ }^{* *}<0.01$ compared to old, respectively. 

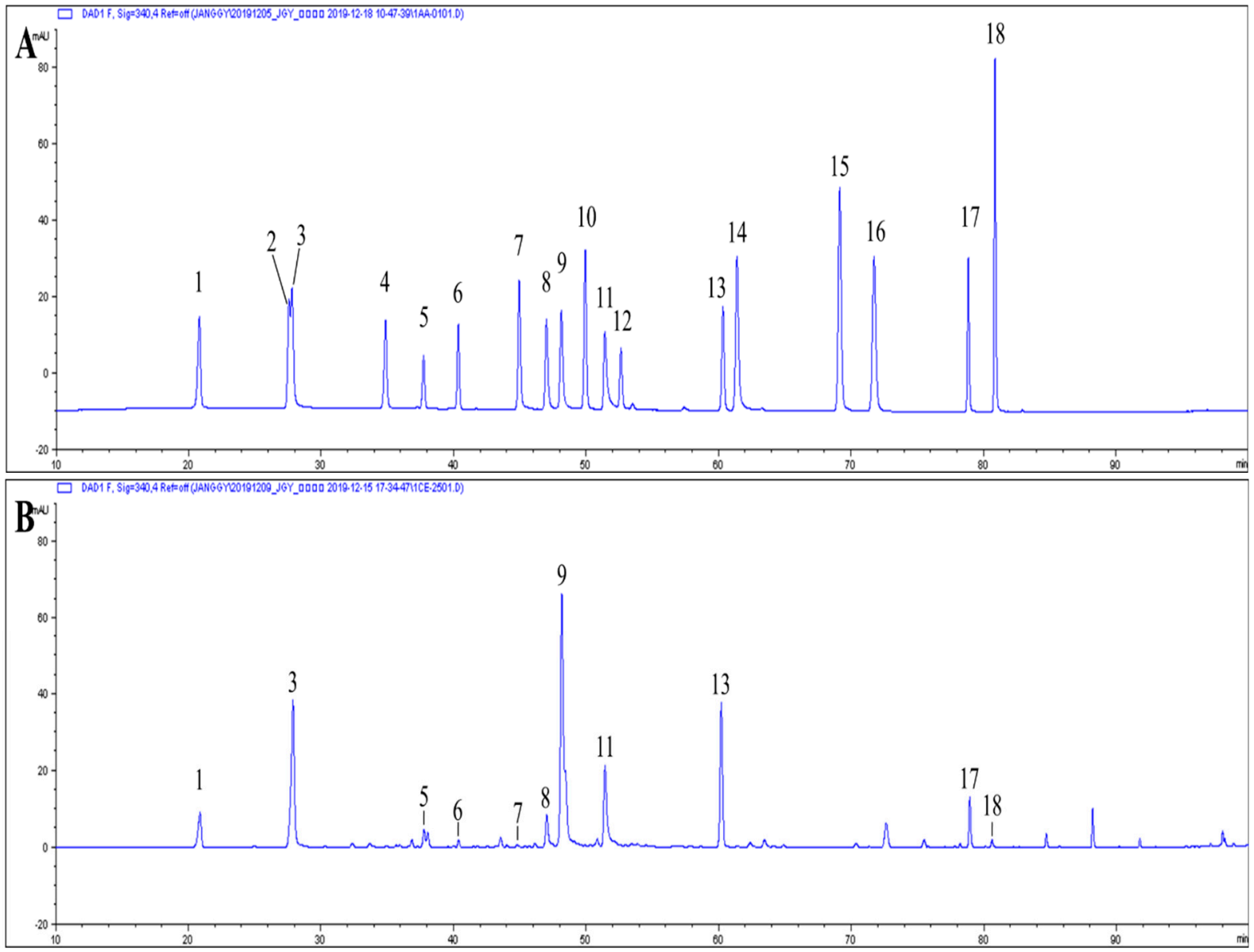

Figure 7. Typical chromatograms of Dendranthema zawadskii (DZ) extract using a HPLC-UVD. (A) Standards (1: neochlorogenic acid; 2: chlorogenic acid; 3: 4-O-caffeoylquinic acid; 4: 1,3-di-O-caffeoylquinic acid; 5: vicenin-1; 6: isoschaftoside; 7: luteolin 7-O-glucoside; 8: isochlorogenic acid B; 9: isochlorogenic acid A; 10: apigenin 7-O-glucoside; 11: isochlorogenic acid C; 12: diosmetin 7-O-glucoside; 13: linarin; 14: luteolin; 15: apigenin; 16: diosmein; 17: eupatorin; 18: acacetin); (B) DZ extract.

Table 1. Major phenolic compounds of Dendranthema zawadskii (DZ) extract.

\begin{tabular}{cccc}
\hline Phenolic Compounds (1) & \multicolumn{3}{c}{ Content $(\mu \mathrm{g} / \mathbf{g}$ Extract, d.b.) } \\
\hline Neochlorogenic acid & 5091.90 & \pm & 105.83 \\
4-O-caffeoylquinic acid & $16,985.07$ & \pm & 198.14 \\
Vicenin-1 & 1963.01 & \pm & 181.48 \\
Isoschaftoside & 1005.34 & \pm & 66.35 \\
Luteolin 7-O-glucoside & 590.92 & \pm & 62.22 \\
Isochlorogenic acid B & 4365.56 & \pm & 293.59 \\
Isochlorogenic acid A & $26,477.89$ & \pm & 830.66 \\
Isochlorogenic acid C & $10,598.95$ & \pm & 454.09 \\
Linarin & $16,480.55$ & \pm & 399.13 \\
Eupatorin & 4228.48 & \pm & 131.40 \\
Acacetin & 412.72 & \pm & 66.59
\end{tabular}

(1) Chlorogenic acid, 1,3-di-O-caffeoylquinic acid, apigenin 7-O-glucoside, diosmetin 7-O-glucoside, apigenin, and diosmetin were not detected.

\section{Discussion}

Senescence is a phenomenon in which the body functions of organisms degenerate with time, and it ultimately results in death. Senescence of cells, the basic units of organisms, is marked by a reduction in cell division functions. Beta-galactosidase is accumulated in lysosomes of aged cells and is stained blue by X-gal [1]. 
DZ is a perennial plant, which belongs to the order Asterales of the Compositae family. In oriental medicine, the whole plant is used as a treatment for women's health problems, cerebral palsy, loss of appetite, and neuralgia [5].

HDF cells were treated with $0.5 \mu \mathrm{M}$ doxorubicin for $4 \mathrm{~h}$ to induce cellular senescence. SA- $\beta$-gal activity was then measured $72 \mathrm{~h}$ after treatment with DZ extract, which dose-dependently and significantly decreased SA- $\beta$-gal activity in HDFs. This result was consistent with those of previous studies showing that HDFs treated with $500 \mathrm{nM}$ adriamycin for $4 \mathrm{~h}$ showed induction of cellular senescence, while incubation occurred with (-)-loliolide at $1-10 \mu \mathrm{g} / \mathrm{mL}$ or juglanin at $1-10 \mu \mathrm{g} / \mathrm{mL}$ for $3 \mathrm{~d}$. Post-treatment measurement of SA- $\beta$-gal activity revealed a reduction in cellular senescence $[17,20]$.

Senescence researchers have supported the free radical theory that reactive oxygen chronically generated in the body damages cellular components, which induces senescence [2]. Oxidative stress causes inflammatory reactions in blood vessels, which are induced by cell death resulting from the lack of blood supply to peripheral tissues due to vascular degeneration in conditions such as arteriosclerosis. Therefore, if oxidative stress generated in vascular endothelial cells could be eliminated, inflammatory reactions in peripheral tissues could be prevented [21]. Prevention of oxidative stress produced in vascular endothelial cells could also possibly prevent inflammatory reactions in peripheral tissues [2,21-23]. Furthermore, oxidative stress has been implicated in the development of endothelial dysfunction during vascular aging [24]. Therefore, we investigated whether treatment of aged rats with DZ extract would reduce age-related oxidative stress. We assessed the levels of oxidative stress using the dichlorofluorescin diacetate (DCFDA) method to measure levels of ROS in descending aorta homogenates. We tested whether DZ extract treatment of aged rats reduced age-related oxidative stress. The results in aorta tissue showed that the ROS levels in the aged rats were higher than in the young rats; however, DZ extract-fed old rats showed significantly lower ROS levels than old control rats. These results are consistent with those of a study in which aorta tissue samples of 21-month-old rats generated higher ROS levels than those of 7-month-old rats. In addition, 3-6 $\mathrm{mg} / \cdot \mathrm{kg}^{-1} \cdot$ day $^{-1}$ betaine-fed 21 -month-old rats showed lower ROS levels in aorta tissue samples than the same-aged rats that were not fed with betaine [18].

ROS induces redox imbalance in the body and thereby activates NF- $\mathrm{KB}$ during the progress of senescence, which induces inflammation-related genes such as iNOS and COX-2 $[3,22,23]$. Considerable attention has been focused on the hypothesis that NF- $\kappa \mathrm{B}$ activation and inflammation elevated by oxidative stress promote senescence [21,22]. According to this hypothesis, redox imbalance in the body caused by senescence elevates oxidative status due to the failure of reactive species (RS) control, which induces inflammatory reactions. ROS-induced redox imbalance in the body activate NF- $k \mathrm{~B}$ during the progression of senescence, which provides evidence for the age-induced inflammation hypothesis. Furthermore, activated NF- $\mathrm{B}$ induces the expression of inflammation-related genes including tumor necrosis factor (TNF)- $\alpha$ and TNF- $\beta$; interleukin (IL)- $1 \beta$, IL-2, and IL-6; chemokines including IL-8 and regulated on activation, normal $\mathrm{T}$ cell expressed and secreted (RANTES); adhesion molecules including intercellular adhesion molecule (ICAM-1, VCAM-1, and E-selectin); and inflammatory enzymes including inducible nitric oxide synthase (iNOS) and cyclooxygenase-2 (COX-2) [3,22,23].

Aged rats were fed with DZ extract at $0.2-1 \mathrm{mg} \cdot \mathrm{kg}^{-1} \cdot \mathrm{day}^{-1}$ for $7 \mathrm{~d}$, to determine if DZ extract treatment could suppress age-induced NF- $\mathrm{kB}$ activation in aortic tissues. We also tested whether treatment of aged rats with DZ extract could suppress the expression of COX-2 and iNOS induced by NF- $\mathrm{BB}$ activation. When cellular nuclei isolated from rat aortic tissues were examined for NF- $\mathrm{KB}$ production, the level increased more in aged than in young rats. When aged rats were treated with DZ extract at $0.2-1 \mathrm{mg} \cdot \mathrm{kg}^{-1} \cdot \mathrm{day}^{-1}$, NF-кB levels decreased significantly and dramatically compared with untreated aged rats. In addition, DZ extract-fed aged rats showed a significant reduction in senescence-induced $\mathrm{NF}-\mathrm{kB}$ activation and expression of $\mathrm{iNOS}$ and COX-2 induced by NF- $\mathrm{kB}$ translocation. 
Therefore, these results suggest that DZ extract effectively inhibited age-related NF- $\mathrm{kB}$ activation and inflammation.

The main phenolic compounds analyzed in DZ extract were reported to have many physiological properties, such as hepatoprotective and antiviral activity of isochlorogenic acid A [25], antioxidant effect of 4-O-caffeoylquinic acid [26], suppressive effect on oxidative stress and anti-inflammatory effect of linarin $[27,28]$, and anti-inflammatory activity of isochlorogenic acid [29]. Woo et al. [13] reported that total polyphenol and flavonoid contents in $80 \%$ ethanol extracts of the flowers of DZ were as high as $57.09 \pm 0.05$ and $41.00 \pm 0.44 \mathrm{mg} / \mathrm{g}$, respectively. In addition, extracts of the leaves and stems of DZ prepared using $80 \%$ ethanol showed excellent inhibition of lipid peroxidation. It was reported that total flavonoids from Chrysanthemum morifolium extracts improve the learning and memory ability of D-galactose-injected mice. The underlying mechanism involved include its antioxidative effects and functional improvement of the central cholinergic system [30]. The present study found that doxorubicin-induced senescence in HDFs was suppressed and that oxidative stress and suppressed cellular senescence as well as agingrelated inflammation was reduced. These effects are attributable to the activity of the total polyphenols and flavonoids in DZ extracts.

\section{Conclusions}

The results of this study indicate that DZ extract inhibits doxorubicin-induced cellular senescence as it significantly decreased SA- $\beta$-gal activity in HDFs and showed antioxidative and anti-inflammatory efficacies in the aorta of aged rats. This action in the aged animal tissue is attributable to the suppression of aging-related ROS generation, NF- $\mathrm{KB}$ activation, and COX-2 and iNOS expression. This novel finding is valuable, particularly because DZ extract may have a potential role in prevention of skin aging and vascular remodeling and inflammatory responses during aging.

Author Contributions: Conceptualization, H.-Y.C.; Formal analysis, G.-Y.J. and H.-J.N.; Investigation, J.C.; Methodology, G.-S.K.; Resources, J.L.; Writing—original draft, J.C.; Writing—review \& editing, S.-E.L. All authors have read and agreed to the published version of the manuscript.

Funding: This work was supported by the Research R\&D Project (PJ00870003) of RDA, Republic of Korea, and the 2014 Post-Doctoral Fellowship Program of NIHHS, RDA.

Institutional Review Board Statement: Not applicable.

Informed Consent Statement: Not applicable.

Conflicts of Interest: The authors declare no conflict of interest.

\section{References}

1. Dimri, G.P.; Lee, X.; Basile, G.; Acosta, M.; Scott, G.; Roskelley, C.; Medrano, E.E.; Linskens, M.; Rubelj, I.; Pereira-Smith, O. A biomarker that identifies senescent human cells in culture and in aging skin in vivo. Proc. Natl. Acad. Sci. USA 1995, 92, 9363-9367. [CrossRef] [PubMed]

2. Harman, D. Aging: A theory based on free radical and radiation chemistry. J. Gerontol. 1955, 11, 298-300. [CrossRef] [PubMed]

3. Chung, H.Y.; Cesari, M.; Anton, S.; Marzetti, E.; Giovannini, S.; Seo, A.Y.; Carter, C.; Yu, B.P.; Leeuwenburgh, C. Molecular inflammation: Underpinnings of aging and age-related diseases. Ageing Res. Rev. 2009, 8, 18-30. [CrossRef] [PubMed]

4. Shin, H.T.; Kim, Y.S. The Establishment of conservation area and conservation strategy in Ulleung Island(1) flora. Korean J. Environ. Ecol. 2002, 16, 195-216.

5. Lee, C.B. Illustrated Flora of Korea; Hyangmoonsa: Seoul, Korea, 2003.

6. Choi, Y.J. Traditional Plant in Korea; Academic Books: Seoul, Korea, 1992.

7. Shin, G.C.; Shin, Y.C. New Our Talk Large a Dictionary.; Samsung Publishing Company: Seoul, Korea, 1992.

8. Woo, K.S.; Yu, J.S.; Hwang, I.G.; Lee, Y.R.; Lee, C.H.; Yoon, H.S.; Lee, J.S.; Jeong, H.S. Antioxidative activity of volatile compounds in flower of Chrysanthemum indicum, C. morifolium, and C. zawadskii. J. Korean Soc. Food Sci. Nutr. 2008, 37, 805-809. [CrossRef]

9. Seo, J.Y.; Lim, S.S.; Park, J.; Lim, J.-S.; Kim, H.J.; Kang, H.J.; Park, J.H.Y.; Kim, J.-S. Protection by Chrysanthemum zawadskii extract from liver damage of mice caused by carbon tetrachloride is maybe mediated by modulation of QR activity. Nutr. Res. Pract. 2010, 4, 93. [CrossRef] 
10. Gu, D.R.; Hwang, J.-K.; Erkhembaatar, M.; Kwon, K.-B.; Kim, M.S.; Lee, Y.-R.; Lee, S.H. Inhibitory effect of Chrysanthemum zawadskii Herbich var. latilobum Kitamura extract on RANKL-induced osteoclast differentiation. Evid.-Based Compl. Alt. Med. 2013, 2013. [CrossRef]

11. Byun, J.-H.; Choi, C.-W.; Jang, M.-J.; Lim, S.H.; Han, H.J.; Choung, S.-Y. Anti-Osteoarthritic Mechanisms of Chrysanthemum zawadskii var. latilobum in MIA-Induced Osteoarthritic Rats and Interleukin-1 $\beta$-Induced SW1353 Human Chondrocytes. Medicina 2020, 56, 685. [CrossRef]

12. Jung, S.-Y.; Park, S.-H.; Nam, C.-H.; Lee, H.-J.; Lee, Y.-M.; Chang, K.-S. The distribution of vascular plants in Ulleungdo and nearby island regions (Gwaneumdo, Jukdo), Korea. J. Asia-Pacific Biodiv. 2013, 6, 123-156. [CrossRef]

13. Woo, J.-H.; Shin, S.-L.; Lee, C.-H. Antioxidant effect of $80 \%$ ethanol extracts obtained from three Dendranthema species. Korean J. Plant. Res. 2010, 23, 47-53.

14. Yoon, I.K.; Kim, H.K.; Kim, Y.K.; Song, I.H.; Kim, W.; Kim, S.; Baek, S.H.; Kim, J.H.; Kim, J.R. Exploration of replicative senescence-associated genes in human dermal fibroblasts by cDNA microarray technology. Exp. Gerontol. 2004, 39, 1369-1378. [CrossRef]

15. Kim, K.S.; Seu, Y.B.; Baek, S.H.; Kim, M.J.; Kim, K.J.; Kim, J.H.; Kim, J.R. Induction of cellular senescence by insulin-like growth factor binding protein-5 through a p53-dependent mechanism. Mol. Biol. Cell 2007, 18, 4543-4552. [CrossRef]

16. Yang, H.H.; Hwangbo, K.; Zheng, M.S.; Cho, J.H.; Son, J.K.; Kim, H.Y.; Baek, S.H.; Choi, H.C.; Park, S.Y.; Kim, J.R. Quercetin-3-O$\beta$-d-glucuronide isolated from Polygonum aviculare inhibits cellular senescence in human primary cells. Arch. Pharmacal Res. 2014, 37, 1219-1233. [CrossRef] [PubMed]

17. Yang, H.H.; Hwangbo, K.; Zheng, M.S.; Son, J.K.; Kim, H.Y.; Baek, S.H.; Choi, H.C.; Park, S.Y.; Kim, J.R. Inhibitory effects of juglanin on cellular senescence in human dermal fibroblasts. J. Nat. Med. 2014, 68, 473-480. [CrossRef]

18. Lee, E.K.; Jang, E.J.; Jung, K.J.; Kim, D.H.; Yu, B.P.; Chung, H.Y. Betaine attenuates lysophosphatidylcholine-mediated adhesion molecules in aged rat aorta: Modulation of the nuclear factor-kB pathway. Exp. Gerontol. 2013, 48, 517-524. [CrossRef] [PubMed]

19. Choi, Y.J.; Kim, H.S.; Lee, J.; Chung, J.; Lee, J.S.; Choi, J.S.; Yoon, T.R.; Kim, H.K.; Chung, H.Y. Down-regulation of oxidative stress and COX-2 and iNOS expressions by dimethyl lithospermate in aged rat kidney. Arch. Pharm. Res. 2014, 37, 1032-1038. [CrossRef] [PubMed]

20. Yang, H.H.; Hwangbo, K.; Zheng, M.S.; Cho, J.H.; Son, J.-K.; Kim, H.Y.; Baek, S.H.; Choi, H.C.; Park, S.Y.; Kim, J.-R. Inhibitory effects of (-)-loliolide on cellular senescence in human dermal fibroblasts. Arch. Pharmacal Res. 2014, 38, 876-884. [CrossRef] [PubMed]

21. Yu, B.P. Aging and oxidative stress: Modulation by dietary restriction. Free Radic. Biol. Med. 1996, 21, 651-668. [CrossRef]

22. Chung, H.Y.; Kim, H.J.; Kim, J.W.; Yu, B.P. The inflammation hypothesis of aging. Ann. N. Y. Acad. Sci. 2001, 928, 327-335. [CrossRef]

23. Chung, H.Y.; Kim, H.J.; Kim, K.W.; Choi, J.S.; Yu, B.P. Molecular inflammation hypothesis of aging based on the anti-aging mechanism of calorie restriction. Microsc. Res. Techniq. 2002, 59, 264-272. [CrossRef]

24. Zou, Y.; Kim, D.H.; Jung, K.J.; Heo, H.S.; Kim, C.H.; Baik, H.S.; Yu, B.P.; Yokozawa, T.; Chung, H.Y. Lysophosphatidylcholine enhances oxidative stress via the 5-lipoxygenase pathway in rat aorta during aging. Rejuv. Res. 2009, 12, 15-24. [CrossRef]

25. Hao, B.-J.; Wu, Y.-H.; Wang, J.-G.; Hu, S.-Q.; Keil, D.J.; Hu, H.-J.; Lou, J.-D.; Zhao, Y. Hepatoprotective and antiviral properties of isochlorogenic acid A from Laggera alata against hepatitis B virus infection. J. Ethnopharmacol. 2012, 144, 190-194. [CrossRef]

26. Ganzon, J.G.; Chen, L.-G.; Wang, C.-C. 4-O-Caffeoylquinic acid as an antioxidant marker for mulberry leaves rich in phenolic compounds. J. Food Drug Anal. 2018, 26, 985-993. [CrossRef]

27. Han, X.; Wu, Y.C.; Meng, M.; Sun, Q.S.; Gao, S.M.; Sun, H. Linarin prevents LPS-induced acute lung injury by suppressing oxidative stress and inflammation via inhibition of TXNIP/NLRP3 and NF-kB pathways. Int. J. Mol. Med. 2018, 42, 1460-1472 [CrossRef] [PubMed]

28. Kim, B.; Lee, J.H.; Seo, M.-J.; Eom, S.H.; Kim, W. Linarin down-regulates phagocytosis, pro-inflammatory cytokine production, and activation marker expression in RAW264. 7 macrophages. Food Sci. Biotechnol. 2016, 25, 1437-1442. [CrossRef]

29. Su, X.; Zhu, Z.-h.; Zhang, L.; Wang, Q.; Xu, M.-m.; Lu, C.; Zhu, Y.; Zeng, J.; Duan, J.-A.; Zhao, M. Anti-inflammatory property and functional substances of Lonicerae Japonicae Caulis. J. Ethnopharmacol. 2021, 267, 113502. [CrossRef] [PubMed]

30. Chai, R.K.; Zhou, X.M.; Xia, M.L.; Pan, X.Y. Effects of dendranthema morifolium on learning, memory and moving abilities in aging mice induced by D-galactose. Cell Biol. Intern. 2008, 32, S8. [CrossRef] 